\title{
Evaluation of Bio-efficacy of Endomycorrhiza and Lipochitooligosaccarides as Seed Treatment on Chickpea
}

\author{
N. K. Patke*, R. S. Wankhade and Sonal Nage \\ Agriculture Research Station, Dr. Panjabrao Deshmukh \\ Krishi Vidyapeeth, Achalpur- 444805, Mahrashtra, India \\ *Corresponding author
}

\section{Keywords \\ MycoMix, MON90505, Endomycorrhiza and Lipochito oligosaccarides}

\section{Article Info}

Accepted: 07 September 2020 Available Online: 10 October 2020

\section{A B S T R A C T}

A field experiment was carried out to study the bio-efficacy of endomycorrhiza and Lipochitooligosaccarides as seed treatment on chickpea at Agriculture Research Station, Dr. Panjabrao Deshmukh Krishi Vidyapeeth, Achalpur, Dist. Amravati, Mahrashtra during Rabi season of the year 2019-20. A set of eight treatments consist of seed treatment $\mathrm{kg}^{-1}$ of seed as control (untreated), recommended (Rhizobium -25 g + PSB-25g + Trichoderma$04 \mathrm{~g}$ ), endomycorriza (MycoMix-1g), endomycorriza (MycoMix-2g), endomycorriza (MycoMix-4g), endomycorrhiza and lipochitooligosaccarides (MycoMix - $1 \mathrm{~g}+$ MON90505- $0.33 \mathrm{ml}$ ), endomycorrhiza and lipochitooligosaccarides (MycoMix 2g + MON90505- $0.33 \mathrm{ml}$ ) and endomycorrhiza and lipochitooligosaccarides (MycoMix- $4 \mathrm{~g}+$ MON90505- $0.33 \mathrm{ml}$ ) were taken under Randomized Block Design with four replication. The experimental results indicated that, among the various treatments, seed treatment with endomycorrhiza and lipochitooligosaccarides (MycoMix-4g + MON90505 - $0.33 \mathrm{ml}$ ) produced significantly higher number of pods plant $^{-1}$ and grain yield of chickpea $(2025 \mathrm{~kg} / \mathrm{ha})$. It helps to increase soil microbial count, dehydrogenase and phosphate activity. However, the yield levels under seed treatment with endomycorrhiza and lipochitooligosaccarides (MycoMix-4g + MON90505- $0.33 \mathrm{ml}$ ) were at par with recommended seed treatment (Rhizobium $25 \mathrm{~g}+\mathrm{PSB} 25 \mathrm{~g}+$ Trichoderma $-04 \mathrm{~g}$ ). It is further revealed from the data that seed treatment with endomycorrhiza and lipochitooligosaccarides (Mycomix + MON90505) increased 14.84 to $23.17 \%$, grain yield of chickpea as compared to control and 2.27 to $9.66 \%$ increase as compared to recommended seed treatment for chickpea (Rhizobium 25g + PSB25g + Trichoderma $04 \mathrm{~g})$.

\section{Introduction}

Chickpea (Cicer arietinum L.) is a very important legume food crop in arid regions considering as an essential source of protein, lipid, carbohydrates and vitamins for human beings. The growth, development and yield of chickpea (Cicer arietinum L.) is strongly influenced by abiotic factors such as salinity and drought in the arid conditions. The use of 
efficient plant growth promoting bacteria in chickpea production is the best solution to overcome those stresses. One of the most ancient and wide spread mutualistic association concerns the endomycorrhizal symbiosis, in which particular soil fungi, called arbuscular mycorrhizal (AM) fungi, colonize the root of most (74\%) plant families on earth(Van der Heijden et al., 2015).

In tropical agriculture, the major importance of mycorrhizal symbiosis will be in its role in the phosphorus nutrition of the plants, especially because (i) tropical soils are invariably poor in available phosphorus, (ii) many tropical soils are phosphorus fixing, and (iii) phosphatic fertilizers are expensive. In legumes, particularly, the triple symbiosis of legumes, mycorrhizal fungi and rhizobia deserves special attention because legumes are very important sources of protein and phosphorus is necessary for symbiotic nitrogen fixation. In phosphorus deficient soils, the leguminous host plants obtain phosphorus mainly through VA mycorrhizal association.

A symbiosis has been documented between Gram-negative soil bacteria, Rhizobiaceae and Bradyrhizobiaceae, and legumes such as soybean. The biochemical basis of these relationships involves the exchange of molecular signals, the compounds that transmit signals from plants to bacteria include flavones, isoflavones and flavanones and the compounds that transmit signals from bacteria to plants include the final products of expression of bradyrhisobial and rhizobial nod genes known as lipochitooligosaccharides (LHO). The symbiosis between these bacteria and legumes allows legumes to bind the atmospheric nitrogen necessary for plant growth, and thereby eliminate the need for nitrogen fertilizers. The symbiotic interaction is initiated when a plant releases flavonoid compounds that stimulate rhizobial bacteria in the soil to produce "Nodfactors." Nod factors are lipochitooligosaccharide compounds (LCO's). Nod-factors are signaling compounds that induce the early stages of nodulation in plant roots, which lead to the formation of root nodules containing the nitrogen-fixing rhizobial bacteria. Although this process occurs naturally over time in legumes, agricultural procedures have been developed to begin the process earlier. These procedures include providing nitrogen-fixing bacteria to seeds or soil and applying nod factors directly to seeds or soil prior to or at sowing. Nod factors have recently been shown to also enhance the germination, growth and yield of legumes and nonlegumes through processes other than nodulation (Prithivaraj et al.2003).

Although the effects of Nod factors on nodulation have been widely studied and reviewed by Ferguson and Mathesius (2003), the mechanisms for Nod factor effects independent of nodulation are not well understood. Nod factors have also been shown to enhance root development (Olah et al., 2005). These LCO's are released by bacteria into the soil, bind to the roots of leguminous plants, and initiate a cascade of plant gene expression that stimulates formation of nitrogen-fixing nodule structures on legume roots. Alternatively, modified and synthetic LCO molecules can be produced through genetic engineering or chemical synthesis. Synthetic LCO's of the same molecular structure interact with plants and stimulate nodulation in the same manner as naturally produced molecules.

In the present study endomycorrhiza (MycoMix) and lipochitooligosaccarides (MON90505) were used as seed treatment on chickpea.

Hence, an experiment was conducted to study the bio-efficacy of endomycorrhiza 
(MycoMix) and lipochitooligosaccarides (MO N90505) as seed treatment on chickpea.

\section{Materials and Methods}

An agronomic experiment was carried out at Agriculture Research Station, Dr. Panjabrao Deshmukh Krishi Vidyapeeth, Achalpur, Dist. Amravati, Mahrashtra during Rabi season of the year 2019-20. The chickpea crop (var. JAKI-9218) was sown at $45 \times 10 \mathrm{~cm}$ spacing in a gross plot size of $6 \times 3.6 \mathrm{~m}$ with a seed rate of $75 \mathrm{~kg} \mathrm{ha}^{-1}$. The crop was raised using RDF @ 25:50:30 kg N:P:K ha ${ }^{-1}$. The treatments were allotted in field follow the random methods. A set of eight treatments consist of seed treatment $\mathrm{kg}^{-1}$ of seed as control (untreated), recommended (Rhizobium- 25g + PSB -25g + Trichoderma04g), endomycorriza (MycoMix- 1g), endomycorriza (MycoMix-2g), endomycorriza (MycoMix-4g), endomyco-rrhiza and lipochitooligosaccarides (MycoMix-1g + MON90505- $0.33 \mathrm{ml}$ ), endomycorrhiza and lipochitooligosaccarides (MycoMix-2g + MO N90505- $0.33 \mathrm{ml}$ ) and endomycorrhiza and lipochitooligosaccarides (MycoMix-4g + MON90505- $0.33 \mathrm{ml}$ ) were taken under Randomized Block Design with four replication.

The Rhizobium + PSB + Trichoderma, endomycorriza (MycoMix), endomycorrhiza and lipochitooligosaccarides (MycoMix + MON90505) were applied to seed as seed treatment before sowing. Observation on germination, crop vigor, root length, plant population, no of root nodules per plant, no. of pods/plant, No. of seeds/pod, grain yield/ha, microbial count, dehydrogenase activity and phosphatase activity were recorded treatment wise. Data obtained during the course of investigation were subjected to statistical analysis by statistical method as suggested by Panse and Sukhatme (1954) in RBD and conclusions were drawn.

\section{Results and Discussion}

\section{Impact on germination, crop vigor and} root length

Data on seed germination, crop vigor and root length are presented in Table 1. Highest crop vigor at 30 DAS was observed when chickpea seed is treated with endomycorrhiza and lipochitooligosaccarides (MycoMix @ 4 g / $\mathrm{kg}$ seed + MON90505@ 0.33 ml $/ \mathrm{kg}$ seed) $\left(\mathrm{T}_{8}\right)$. The significantly higher root length of chickpea @ 30 DAS was recorded in treatment $\mathrm{T}_{8}$ (Endomycorrhiza and Lipochito oligosaccarides-MycoMix @ 4 g / kg seed + MON90505@0.33ml $/ \mathrm{kg}$ seed). But it was found at par with treatment $\mathrm{T}_{7}$ (Endomycorrhiza and Lipochitooligosaccarides MycoMix @ 2 g / kg seed + MON90505 @ $0.33 \mathrm{ml} / \mathrm{kg} \quad$ seed), $\mathrm{T}_{6}$ (Endomycorrhiza and Lipochitooligosaccarides-MycoMix @ 1 g / kg seed + MON90505@ @ $0.33 \mathrm{ml} / \mathrm{kg}$ seed) and $\mathrm{T}_{5}$ (Mycomix@4g/kg seed).

Mycorrhizal treatments significantly increased the shoot and root lengths reported by Salahedin moradi et al., in chickpea in 2013.

Lipochitooligosaccarides have recently been shown to also enhance the germination, growth and yield of legumes and nonlegumes through processes other than nodulation (Prithivaraj et al., 2003).

Lipochitooligosaccarides i.e. nod factors have also been shown to enhance root development (Olah, et al., 2005).

\section{Impact on plant population and no. of nodules per plant}

Plant population of chickpea at 30 and 60 DAS showed non-significant effect due to various treatments (Table 1). Significantly 
higher No. of nodules per plant at 30 and 60 DAS were recorded in endomycorrhiza and lipochitooligosaccarides (MycoMix@4 g/ $\mathrm{kg}$ seed + MON90505@0.33ml/kg seed) $\left(\mathrm{T}_{8}\right)$. However, it remained at par with other treatments except treatment $\mathrm{T}_{3}$ (Endomycorrhiza and Lipochitooligosaccarides- MycoMix @ 1 g / kg seed) and control $\left(\mathrm{T}_{1}\right)$.

\section{Impact on yield contributing characters and grain yield of chickpea}

Significantly higher no. of pods/plant of chickpea were recorded in treatment $\mathrm{T}_{8}$ (Endomycorrhiza and Lipochito oligosaccarides-MycoMix @4 g / kg seed + MON90505@0.33ml $/ \mathrm{kg}$ seed). However, it was found at par with treatment $T_{7}$ (Endomycorrhiza and Lipochito oligosaccarides-MycoMix @ 2 g / kg seed + MON90505 @ $0.33 \mathrm{ml} / \mathrm{kg} \quad$ seed), $\quad \mathrm{T}_{6}$ (Endomycorrhiza and Lipochitooligo saccarides-MycoMix@ 1 g / kg seed + MON90505 @ $0.33 \mathrm{ml} / \mathrm{kg} \quad$ seed), $\mathrm{T}_{5}$ (Endomycorrhiza and Lipochitooligo saccarides-MycoMix @ 4 g / kg seed), $\mathrm{T}_{4}$ (Endomycorrhiza and Lipochitooligo saccarides-MycoMix @ 2 g / kg seed) and $\mathrm{T}_{2}$ (recommended practice). No. of seeds per pod does not affect significantly due to various seed treatments.

Grain yield of chickpea is significantly influence by various seed treatments. Seed treatment with endomycorrhiza and lipochitooligosaccarides (MycoMix @ 4 g / $\mathrm{kg}$ seed + MON90505@0.33ml/kg seed) recorded significantly higher grain yield of chickpea $(2025 \mathrm{~kg} / \mathrm{ha})$ followed by $\mathrm{T}_{7}$ (Endomycorrhiza and Lipochitooligo saccarides- MycoMix @ 2 g / kg seed + MON90505 @ $\quad 0.33 \mathrm{ml} / \mathrm{kg} \quad$ seed), $\quad \mathrm{T}_{6}$ (Endomycorrhiza and Lipochitooligo saccarides -MycoMix @ 1 g / kg seed + MON90505 @ $\quad 0.33 \mathrm{ml} / \mathrm{kg} \quad$ seed), $\quad \mathrm{T}_{5}$
(Endomycorrhiza and Lipochito oligosaccarides-Mycomix @ 4 g / kg seed), $\mathrm{T}_{4}$ (Endomycorrhiza and Lipochito oligosaccarides-Mycomix @ 2 g / kg seed) and $\mathrm{T}_{2}$ (recommended practice). However, these treatments were at par with each other. Lowest grain yield of chickpea was recorded in control treatment.

It is further revealed from the data that seed treatment with endomycorrhiza and lipochitooligosaccarides (MycoMix + MON90505) increased 14.84 to $23.17 \%$, grain yield of chickpea as compared to control and 2.27 to $9.66 \%$ increase as compared to recommended seed treatment for chickpea (Rhizobium + PSB+ Trichoderma).

Erman et al., (2011) showed that application of endomycorrhiza AM significantly increased the growth and yields of chickpea.

Lipochitooligosaccarides have recently been shown to enhance yield of legumes and nonlegumes through processes other than nodulation (Prithivaraj et al.2003).

\section{Impact on microbial count, dehydrogenase} activity and phosphatase activity

Microbial count (fungi) was recorded at $50 \%$ flowering showed significant results due various seed treatments. With the increase in dose of endomycorrhiza (MycoMix) for seed treatment either alone or in combination with lipochitooligosaccarides (MON90505), significant increase in microbial count in soil was recorded.

Significantly maximum dehydrogenase activity in soil per $24 \mathrm{hrs}$ was recorded in seed treatment with endomycorrhiza and lipochitooligosaccarides (MycoMix @ 4 g / $\mathrm{kg}$ seed + MON90505 @ 0.33ml $/ \mathrm{kg}$ seed). Similar trend was recorded in Phosphate activity per $24 \mathrm{hrs}$. 
Table.1 Evaluation of bio-efficacy of Endomycorrhiza (MycoMix) and Lipochitooligosaccarides (MON90505) as seed treatment on chickpea

\begin{tabular}{|c|c|c|c|c|c|c|c|c|c|c|c|c|c|c|c|}
\hline$\dot{\vec{B}} \dot{z}$ & 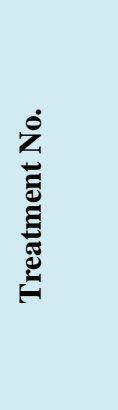 & 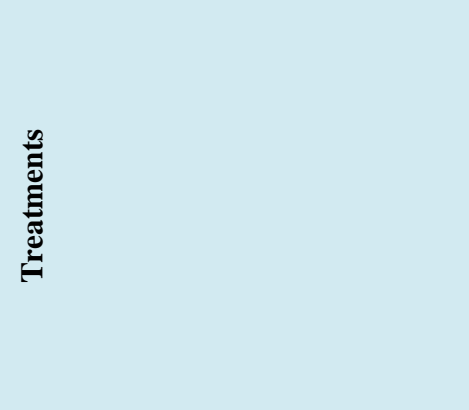 & 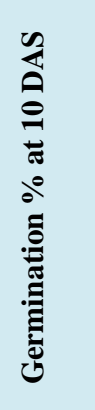 & 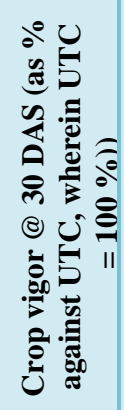 & 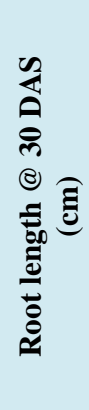 & 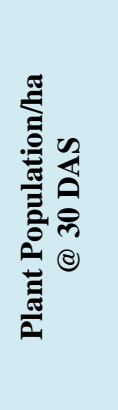 & 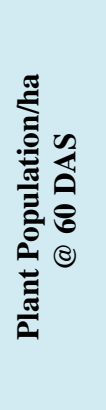 & 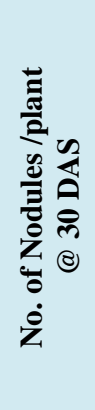 & 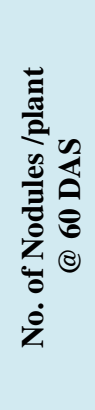 & 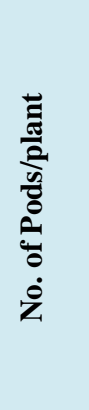 & 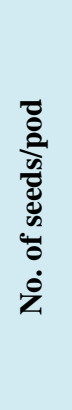 & 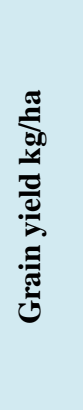 & 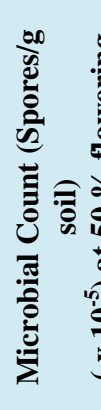 & 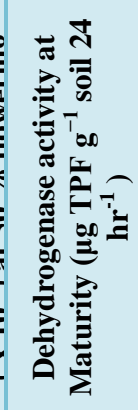 & 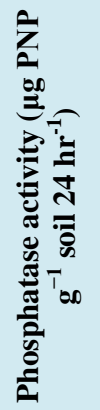 \\
\hline 1 & $\mathrm{~T} 1$ & UTC (Untreated control) & 91.77 & 100.00 & 11.65 & 197915 & 192013 & 20.17 & 26.40 & 24.26 & 1.05 & 1644 & 10.11 & 34.85 & 174.03 \\
\hline 2 & $\mathrm{~T} 2$ & $\begin{array}{l}\text { Recommended (Rhizobium } 25 \mathrm{~g}+ \\
\text { PSB } 25 \mathrm{~g}+\text { Trichoderma- } 04 \mathrm{~g} \text { ) }\end{array}$ & 93.13 & 120.00 & 13.80 & 201388 & 193633 & 30.75 & 38.33 & 30.27 & 1.10 & 1846 & 13.77 & 38.53 & 182.48 \\
\hline 3 & $\mathrm{~T} 3$ & Endomycorrhiza (MycoMix 1g) & 92.03 & 120.00 & 12.15 & 199999 & 192591 & 26.91 & 33.91 & 28.03 & 1.10 & 1709 & 12.92 & 39.65 & 178.93 \\
\hline 4 & $\mathrm{~T} 4$ & Endomycorrhiza (MycoMix 2g) & 92.29 & 120.00 & 12.28 & 200809 & 193170 & 28.50 & 35.83 & 29.86 & 1.10 & 1780 & 13.83 & 40.14 & 188.73 \\
\hline 5 & T5 & Endomycorrhiza (MycoMix 4g) & 93.07 & 120.00 & 13.40 & 200693 & 194212 & 30.00 & 36.75 & 30.10 & 1.10 & 1862 & 14.20 & 40.48 & 191.10 \\
\hline 6 & T6 & $\begin{array}{l}\text { Endomycorrhiza and } \\
\text { Lipochitooligosaccarides( } \\
\text { MycoMix- 1g + MON90505- } \\
0.33 \mathrm{ml})\end{array}$ & 93.23 & 125.00 & 13.95 & 201272 & 195369 & 31.33 & 38.41 & 30.28 & 1.10 & 1888 & 14.68 & 41.42 & 193.40 \\
\hline 7 & $\mathrm{~T} 7$ & $\begin{array}{l}\text { Endomycorrhiza and } \\
\text { Lipochitooligosaccarides(MycoMix } \\
-2 \mathrm{~g}+\text { MON90505- } 0.33 \mathrm{ml})\end{array}$ & 93.49 & 125.00 & 14.28 & 202892 & 196064 & 32.00 & 39.16 & 31.44 & 1.10 & 1923 & 15.06 & 41.59 & 199.98 \\
\hline \multirow[t]{3}{*}{8} & $\mathrm{~T} 8$ & $\begin{array}{l}\text { Endomycorrhiza and } \\
\text { Lipochitooligosaccarides } \\
\text { (MycoMix- } 4 \mathrm{~g}+\text { MON90505 - } \\
0.33 \mathrm{ml} \text { ) }\end{array}$ & 93.65 & 130.00 & 14.48 & 203124 & 197800 & 32.75 & 39.91 & 31.80 & 1.10 & 2025 & 15.21 & 43.76 & 203.38 \\
\hline & $\begin{array}{l}\text { SE }(M) \\
\pm\end{array}$ & & 0.57 & - & 0.73 & 1511 & 1424 & 1.80 & 1.65 & 1.05 & 0.06 & 82 & 0.25 & 0.43 & 2.64 \\
\hline & $\begin{array}{l}\text { CD @ } \\
\mathbf{5 \%}\end{array}$ & & NS & - & 2.13 & NS & NS & 5.29 & 4.84 & 3.10 & NS & 241 & 0.74 & 1.26 & 7.76 \\
\hline
\end{tabular}


The dehydrogenase activity denotes soil microbial biomass. Mandal et al., (2007) reported a closer relationship between the soil microbial biomass and crop yields under both greenhouses as well as field conditions.

Microorganisms in soil played an important role in nutrient cycling and plant nutrition, reduced pathogen populations, increased soil organic matter, total carbon, cation exchange capacity, and lowered bulk density thus improving soil quality (Bulluck et al., 2002).

In conclusion, the results of present investigation suggest that, among the various treatments, seed treatment with endomycorrhiza and lipochitooligosaccarides (MycoMix@ 4 g / kg seed + MON90505@ 0.33ml $/ \mathrm{kg}$ ) produced significantly higher number of pods plant ${ }^{-1}$ and grain yield of chickpea. It helps to increase soil microbial count, dehydrogenase and phosphate activity. Seed treatment with endomycorrhiza and lipochitooligosaccarides (MycoMix @ 4 g/ kg seed + MON90505@0.33 ml $/ \mathrm{kg}$ ) would be more beneficial to the farmers due to increased number of pods plant $^{-1}$ and grain yield. However, the yield levels under seed treatment with endomycorrhiza and lipochitooligosaccarides (MycoMix @ 4 g / kg seed+MON90505@0.33ml/kg) were at par with recommended seed treatment (Rhizobium + PSB+ Trichoderma).

\section{References}

Bulluck L R, Brosius M, Evanylo G K, Ristaino J B (2002). Organic and synthetic fertility amendments influence soil microbial, physical and chemical properties on organic and conventional farms. Appl Soil Ecol. 19:147-160.

Erman M, Demirb S, Ocakc E, Tüfenkci S, Oguz F, Akkopru A. (2011). Effects of Rhizobium, arbuscular mycorrhiza and whey applications on some properties in chickpea (Cicer arietinum L.) under irrigated and rainfed conditions- Yield, yield components, nodulation and AMF colonization. Field Crops Research. 122:14-24.

Mandal A, Patra A K, Singh D, Swarup A, Masto R E (2007). Effect of long-term application of manure and fertilizeron biological and biochemical activities in soil during crop development stages. Bioresour Technol. 98:3585-3592.

Panse, V.G. and Sukhatme P.V., 1978. Statistical Methods for Agricultural Workers. ICAR Publication, New Delhi.

Prithivaraj B., Zhou X., Souleimanov A., Kahn W.M. and Smith D. L. (2003), A host specific bacteria -to-plant signal molecule (Nod factor) enhances germination and early growth of diverse crop plants. Planta. vol. 216, 437-445.

Salahedinmoradi, Jamal sheikh and mehdizarei. (2013). Effects of arbuscular mycorrhizal fungi and rhizobium on shoot and root growth of chickpea in a calcareous soil. International Journal of Agriculture: Research and Review. Vol., 3(2), 381-385.

Van der Heijden, M. G., Martin, F. M., Selosse, M. A., and Sanders, I. R. (2015). Mycorrhizal ecology and evolution: the past, the present, and the future. New Phytol.205, 1406-1423. doi: 10.1111/nph.13288

Ferguson Brett James and Mathesius Ulrike. (2003). Signaling interactions during nodule development. J. Plant Growth Regulation, vol. 22, 47-72.

Olah Boglarka, Christian Briere, Guillaume Becard, Jean Denarie and Clare Gough. (2005). Nod factors and a diffusible factor from arbuscular mycorrhizal fungi stimulate lateral root formation in Medicagotruncatula via the DMI1/DMI2 signalling pathway. The Plant Journal. vol. 44, 195-207.

\section{How to cite this article:}

Patke, N. K., R. S. Wankhade and Sonal Nage. 2020. Evaluation of Bio-efficacy of Endomycorrhiza and Lipochitooligosaccarides as Seed Treatment on Chickpea. Int.J.Curr.Microbiol.App.Sci. 9(10): 659-664. doi: https://doi.org/10.20546/ijcmas.2020.910.079 